\author{
DOSSIÊ \\ AUDIOVISUAL \\ JOURNALISM: \\ from the tv screen to other screens \\ Copyright () 2012 \\ SBPjor / Brazilian \\ Association \\ of Journalism \\ Researchers \\ FRANCISCO MACHADO FILHO \\ Universidade Estadual Paulista Júlio de Mesquita \\ MAYRA FERNANDA FERREIRA \\ Universidade Estadual Paulista Júlio de Mesquita
}

\begin{abstract}
This article is based on research which has been developed in partnership with Unesp TV, a university TV broadcast station of the Universidade Estadual Paulista Julio de Mesquita Filho, Bauru campus/SP. The study aims to identify convergent and divergent aspects in the design of audiovisual journalistic content for TV and other media such as the internet and mobile communication systems. The results presented here are the considerations obtained from the first stage of the research. In this phase, the basic steps which should guide the design of the content to feed broadcasting time are outlined, as well as the online audiovisual news broadcast and business management of a TV station, compared to the model which has been followed by internet TV broadcasters.
\end{abstract}

Keywords: Digital migration. Audiovisual journalism. TV journalism.Broadcasting TV.

\title{
JORNALISMO AUDIOVISUAL: da tela da TV para outras telas
}

RESUMO - O presente trabalho é fruto de uma pesquisa em desenvolvimento em parceria com a TV Unesp, emissora universitária vinculada à Universidade Estadual Paulista Júlio de Mesquita, campus de Bauru/SP e que tem por objetivo identificar os pontos convergentes e divergentes na produção de conteúdo audiovisual informativo para a TV aberta e demais plataformas digitais e móveis. O texto em questão é a conclusão da primeira etapa da pesquisa que se pautou por identificar os pressupostos básicos que deverão nortear os conteúdos que serão produzidos posteriormente e veiculados pela emissora no decorrer da pesquisa. Foram analisadas as características do jornalismo audiovisual online e o modelo de negócios da TV aberta em contraste com o modelo de negócios presente na Internet.

Palavras-chave: Migração Digital. Jornalismo Audiovisual. Telejornalismo. TV Aberta.

\section{PERIODISMO AUDIOVISUAL: De la pantalla de TV a otras pantallas}

RESUMEN - Este trabajo es el resultado de una investigación todavía en curso, en colaboración con la TV Unesp, una emisora vinculada a la Universidade Estadual Paulista Júlio de Mesquita, campus de Bauru (São Paulo), que tiene como objetivo identificar los puntos convergentes y divergentes en la producción de contenidos de información audiovisual para televisión y otras plataformas digitales y móviles. El texto en cuestión es la conclusión de la primera etapa de la investigación en la cual se identificaron los supuestos básicos que deben guiar los contenidos que posteriormente se producirán y serán difundidos por la emisora en el transcurso de la investigación. Se analizaron las características del periodismo audiovisual en línea y el modelo de negocio de televisión abierta, en contraste con el modelo de negocio actual en Internet.

Palabras clave: Migración digital. Periodismo audiovisual. Periodismo. Televisión Abierta. 


\section{Introduction}

The worldwide web of computers, the Internet, has come to transform the communications industry throughout the world by making it possible for audiovisual content, previously conditioned to the screen of a television set, to be conveyed via other kinds of devices, such as cell-phone appliances, tablets, personal computers and notebooks. In Brazil, due to the popularization of the access to internet systems via broadband, as well as the arrival of the so-called C class to the consumer market through adhering to these new communication and information platforms for content distribution, the television industry has begun to feel the effects of the new tools and their boundless potential, mainly via wireless devices. However, it is necessary to understand the transformations caused by the advent and popularization of the Internet and distribution of audiovisual information, as well as the consequent adaptation of the television industry, which is required by this new communicational scenery. This article aims to present some research results, still in progress, which has been developed in partnership with TV Unesp in Bauru, with the aim of identifying the main converging or diverging points in the format, language and production of news under a journalistic paradigm for both network TV channels and audiovisual journalism distributed via internet or cell phone networks.

In the first stage of the study, a bibliographic, descriptive approach to the issue is adopted, grounded mainly in "the description of the characteristics of a given population or phenomenon" (GIL, 1991, p. 42.) Thus, the research carries out a survey under the theoretical framework that has been used in the production of new formats of audiovisual journalism beyond the television screen. This article is therefore the fruit of this first phase, in which it analyzes the characteristics of visual journalism online and the business model of network TV in contrast with the current business model followed for this on the Internet.

In the second phase of the research, audiovisual products will be accessed and applied to focus groups with the objective of checking the converging or diverging points on an audiovisual information product, thus, establishing a referential bridge between the productions of this genre and format for network TV and the internet ones. This data will be disclosed later. 


\section{Journalism and web}

With the popularization of the Internet in the 1990s, providing users with almost unrestricted and unlimited access to information, journalism, already carried out on other media, envisioned in this environment a new space for the dissemination of news. The first steps were taken by printed vehicles that have built sites to make their content available also in digital format. According to Gonzales (2000 apud CANAVILHAS, 2007), this first phase of journalism on the Internet is termed "facsimile", given that a printed issue of a newspaper was digitalized and made available in full for the readers on the new platform. From the moment some features of this digital medium beccame recognized, the second phase of internet journalism was initiated; online or adapted, model. In this phase, printed newspapers had their content displayed online in their own web layout. It is worth noting that the news was the same, from language to content.

The scene began to change during the third phase, when digital journalism itself arose. In addition to having its own layout, hypertextuality, a space for comments and a section for the latest news, were inserted on websites that are emerging on the web, as well as on sites linked to printed and audiovisual means of communication. When promoting a link to complementary information, the journalistic websites build a kind of architecture for the information based on the hypertext. For Lévy (1996), the hypertext is composed of knots of information tied up by connections; each knot is a text - representing only a word, a page, images, graphics or sound sequences.

Functionally, a hypertext is a type of program for knowledge or data organization, information and communication acquisition, with the functions of "hierarchizing and selecting meaningful areas, presenting links between those zones, to connect the text to other documents and be supported by a cultural memory" (LÉVY, 1996, p. 37). As this type of text is defined by its interconnections, associations and remissions that can be obtained effectively between the information, its structure breaks the linear flow that is unique to the language in other means of communication.

Today, information online or in cyberspace, in general, includes not only deterritorialized 'stocks' of texts, images and usual sounds, but equally hypertextual points of view on these stocks, knowledge bases with capacities for autonomous inference and available digital models for all the simulations. (LÈVY, 1996, p. 115).

This non-linearity in the connection between the hypertexts, through the links, characterizes the interactivity of the hypermediatic 
language, since, while storing the information and organizing it within us, navigation routes, which vary from one user to another, are set up according to the links that will be clicked on by both key pals. "That is only possible due to the hyper structure, not sequential, but multidimensional, which gives support to infinite options" (SANTAELLA, 2004, p. 49). Allied to this interaction' via hypertext, users gain a space to approach news through posted comments. Considering this possibility also as a form of interaction, has strengthened the theory that the Internet is "the means of universal interactive communication via computer in the information age" (CASTELLS, 2002, p. 433). Even as a brief manifestation of opinions about the topic available on the website, there is once again the choice from the person surfing the informative pages, due to the range of posted news, especially when the internet reader adopts updating resources almost instantaneously vis-à-vis the occurring event.

It is from these characteristics that journalism enters its third phase on the worldwide web, presenting the elements that, as per Palacios (2003), help to build the digital media: updating, hypertextuality, personalization, memory, multimediality and interactivity. The first two ones have been set out above. Personalization allows journalistic products to be tailored to the interests of users; the news to which a certain reader has access is a reflection of their preference, given that they can configure the newspaper online so as to receive it. Another aspect to be taken into consideration is memory, which particularizes this kind of journalistic production because it is possible to stock information through the knots in the network, making them available to internet users and news makers. "The possibility of linking fresh news to previous news allows the enrichment of journalism itself thanks to the contextualization of the phenomenon."(CANAVILHAS, 2006, p. 5).

Multimedia character refers to the convergence of the traditional media for text producing, image and sound in the narration of the journalistic fact. The interactivity allows users to participate in the process while sending e-mails and comments on a piece of news, in addition to the opportunities to take part in discussion and chat forums on a given subject with other users or with the journalists themselves. These two aforementioned characteristics guide the latest phase of journalism, currently under way, the multimedia model, which defines web journalism. In this model, the features of multimediality and interactivity, which distinguish digital media from any other means of communication, have become more prominent in journalism. Canavilhas (2007) points out that this term is the one which is better adapted to the characteristic 
of the means.

\begin{abstract}
It seems to us that the word webperiodism is the most appropriate one for journalism carried on and for the Internet, more specifically, in the part of Internet called World Wide Web. Therefore, what we understand by webperiodism is the journalism that uses internet tools to investigate and design journalistic contents spread throughout the Web, and that has its own language composed of texts, sounds, images and animations, interconnected through hyperlinks (CANAVILHAS, 2007, p. 6-7). ${ }^{2}$
\end{abstract}

Although in theory it is not difficult to notice the differences between web journalism compared to practice in traditional means of communication, Canavilhas (2007) believes that this process itself is still at an incipient phase, facing the challenge of how to appropriate hypertextual, multimediatic and interactive language. This is the case because the adoption of those characteristics requires not only preparation but also internal structure of editing journalism sections. According to the author, there are few newspapers which maintain a web-journalism team devoted to producing online newspapers, as hypertextual, multimedia elaboration requires both more technique and time to produce the news. These are factors that very often do not exist in a newspaper's production routine.

\title{
The point is not only the content
}

The point of content in online journalism is one of the main issues to be observed when using this kind of media tool to spread journalistic contents. But this new tool does not only involve the content and textual, semantic or lexical adaptations to the new means that will allow the available information on the web to reach the addressees. It is important to understand certain processes, routines and how the web itself works, in order to understand how the information tracks its "knot" of this huge web, called the Internet. This production protocol is linked directly to information architecture.

Information architecture is the art and science of organizing information to help individuals satisfy their informational needs (ROSENFELD apud EWING, MAGNUSON; SCHANG, 2003). It includes the organization, navigation, the titling and the search media tools of information systems, and is part of the analysis, design and implementation of any informational space (AGNER, 2002). Thus, producing and making available any information on the web cannot have the same structure as an audiovisual product from the analogical system of production, or even the same as vehiculated on a digital network TV 
broadcast.

The building of internet journalism, as mentioned by Canavilhas (2007), is in its initial stages. Its history is recent, in spite of the numerous transformations this genre of journalism has undergone. The relationship it has with the offline means renders it simultaneously conflictual and friendly. Ultimately, journalistic means keep the precepts of journalism (present, universality, periodicity and diffusion) alive and each one in its particular fashion. In addition, such means are influenced by the others, aggregating their characteristics to web journalism. Publishing in newspapers, magazines, on radio or TV shows, websites, and more recently on online social networks, has required that journalism face becoming more and more current, universal, periodic and diffuse to readers. The means this new kind of writing entails is mainly the need constantly to reshape, seeking to present the latest fact(s) in the text without becoming absorbed with the incessant search for breaking news. This new journalistic text has also established a new viewership for its products in order to satisfy the interests of a different audience. In spite of the instantaneousness in the flow of information, periodicity still needs to be considered in order to win over and maintain the audience. Ultimately, due to the speed of the information, the reach of the journalistic content is even greater, which should represent a bigger concern for the media.

As web journalism comes from classic offline models, its production, editing and publishing forms maintain certain characteristics of those genres, but in a new format and language. Therefore, the information speed on online means and the multimediatic-interactive potentialities available in the virtual environment leading to a new journalistic routine, do not pose difficulties in continuing to search for informative quality and credibility. Achieving a balance between the characteristics of digital media, with the precepts and social commitment of journalism, is one of the greatest challenges to overcome. According to Eugênio Bucci in the lecture "The role of media in the digital society", journalistic mediation is still essential for the formation of public opinion. Thus, it is a journalist's duty to enrich information that has already been in circulation on the Internet. Nonetheless, the challenge can only be overcome through a convergent journalistic formation so that textual, video and audio technology, can be allied with the social responsibility that is embedded in journalism. On this point, Briggs (2007) and Prado (2011) emphasize the role of this new professional, who must master the techniques and maintain journalistic tact as a target to write, select, edit and distribute the content, be it factual or not. 


\title{
The business model as a structuring factor of genre and format
}

The journalism practiced on television has been structured over time almost simultaneously to the deployment of television. Souza (2004) explains that, in the beginning, evening news "was leveraged by multinational sponsors that already knew the importance of gender in their countries of origin" (SOUZA, 2004, p. 150). With the fall in prices and popularity of TV, advertising became stronger in the media and the main way of financing programming. This business model was established under Federal Brazilian Law 4,117, from August 27, 1962. Article 6 provides that network TV should be offered directly and free of charge to the public. This has led to the creation of a need for a business model to enable broadcasters to remain economically viable. Thus, the use of advertising throughout programming breaks has consolidated itself as a business model. This first occurred on the radio and, later, on television, in the US. Anderson (2009) reports that, at the beginning, this model was not well regarded, but some broadcasters such as NBC, were confident that propaganda could finance its programming on both radio and television.

\begin{abstract}
Both radio and television were free and paid for by advertising. It was the beginning of the so-called model for Free: a third party (the advertiser) subsidized the content, so that one of the parties (the listener or viewer) could receive it free of charge (ANDERSON, 2009, p. 139). ${ }^{3}$
\end{abstract}

This model is still in place today, with greater emphasis on network TV broadcasters both in the US and Brazil, and also on cable and satellite television, but to a lesser extent, since these two modalities of TV receive monthly payments from subscribers. Telejournalism has been adapting itself to the model. The main network television news broadcasting stations in Brazil are programmed within the time frame known as "prime time". Televised news editions are scheduled together with soap operas, which have the largest viewership on Brazilian TV, demonstrating that there has been a hierarchy in news aiming to keep spectators waiting for the most important news of the day, inside preprogrammed news blocks that build up a characteristic narrative for this text.

\footnotetext{
The narrative of television news broadcasts is, therefore, structured and built around the blocks, separated by commercial intervals, responsible for the four principles of enunciation of the discourse of news: "relaxation, fragmentation, dramatization and marketing". The attention gained by this procedure can be diluted early during
} 


\begin{abstract}
the first break. Therefore, at the end of the blocks, there is a call, the unfolding of the block, to sharpen one's curiosity or awaken the viewer's interest regarding the news that will be transmitted after the commercial break. Programs must seduce and win over audiences the whole time (BECKER, 2005, p. 77-78) ${ }^{4}$
\end{abstract}

As with any TV show, the evening news should have a relative audience in order to attract advertisers and ensure a billing that makes the program. However, "with the Web, a means in which the media is not in a privileged position, this model is no longer capable of sustaining anything by itself." (ANDERSON, 2009, p. 139) ${ }^{5}$

As a result of web popularization, the size of TV audiences has been decreasing throughout the world, and with this, the model of the gratuitousness supplied by advertisers could soon collapse. Hence, the smaller the audience, the lower the investment in advertising on television by the advertisers. The latter will thus follow the audience wherever they go or wherever the cost/benefit relationship appears most efficient.

\title{
A new audience on a new format
}

In the new society that has been designed and structuring itself as an interconnected network (CASTELLS, 2002), in which segmentation and personalization are constant goals, the main economic source of network TV broadcasters has been challenged. Network communication done through the Internet has been changing not only the way individuals communicate with one another but also the relation between communication and power, because, since it is happening, the logic that standardizes and governs communicational aspects become the network logic and not the logic of a communication designed to communicate with an indistinct mass of individuals, or categorized based around similar social demographic characteristics presented by the web-journalistical communication produced, a characteristic of society throughout the industrial age.

Traditional media vehicles were devised to supply the demand of the industrial age; it is not by chance that they were called mass media vehicles. Surplus produced by factories found in publicity and marketing a very efficient way to reach the consumer and thus, the mediatic industry has been designed according to a business model which aims to reach the audience with publicity messages, getting more and more TV viewers, readers or listeners. However, in network communication (where the mass is becoming more and more fragmented into smaller groups and subgroups), if products do not satisfy those who consume the traditional 
media and are interconnected by the internet at the same time, these vehicles can be excluded from their relationship and, consequently, present a meaningful loss in both audience and income, as it is possible that the audience might migrate to a new platform which provides them with the same or even better cognitive experiences.

So, the strategies of production, commercialization, content distribution and engagement of the audience which had been practiced by mass communication vehicles until the industrial age do not have a place in network communication. The great challenge for communication vehicles nowadays is: while this transitional condition lasts, to feature on structured vehicles outlined by the paradigms practiced throughout the industrial age and, at the same time, to meet a growing demand for segmented products for an audience that do not consume television as it did 20 years ago but which still belongs to a receptive consumer mass of propaganda messages, a kind of audience that also interact and consume communicational products through social networks and new communicational platforms of highly personalizing and individualizing content distribution. How can it stop being a mass communication vehicle and become a communication vehicle capable of captivating such a varied range of consumers (niches), which has been forming a new social mass? Indeed, can this be done on network TV?

Since 1977, when terrestrial television networks in the US started to experience a decrease in their audience levels (DIZARD, 2000), there have been important changes in the programming schedules. Program structures now feature the same number of blocks and commercials simultaneously on rival TV networks, merchandizing takes place on live or edited shows. These are some of the actions taken by broadcasters in an attempt to minimize sponsors' losses during commercial breaks. There have also been changes in the schedule, language and format of the shows, which have adapted to the new reality. Reality Shows are not a novelty on worldwide TV; Jenkins (2008) cites TV shows like COPS (1989) and Real World, both from MTV (1989), as successful examples of the genre on North American TV. From 2000, there has also been a proliferation of reality TV shows that have appealed to the whole world. Big Brother, Survivor and American Idol are examples of TV shows that have achieved franchising across all continents ${ }^{6 .}$

Jenkins (2008) presents an important analysis about reality shows at a time when the cost of a 30 -second ad has been decreasing systematically on both network and private broadcasters around the world (JAFE, 2005). This kind of show has been used to design what 
the author calls an economy based on affectivity which "incentivizes companies to change the trade marks into the so-called lovermarks and become the border between entertainment contents and less perceptible propaganda messages". (JENKINS, 2008, p. 46)

Lovermarks are those people who love a certain TV-show brand so much that they become loyal consumers of it. The success of reality shows is intrinsically linked to network communication and the online interaction about them because the TV show is not simply a success on TV screens, but also off-screen. Jenkins (2008) states that TV shows like Survivor have generated countless virtual communities on the internet. In this kind of virtual environment, anything related to the beloved TV show is discussed, promoted and broadcast. These consumers spread around the internet love the brand (in this case the TV show), and Survivor became the first successful affair in which both traditional and digital media converged to commercialize a product (JENKINS, 2008, p. 91). For the author, this convergence was only possible due to the Internet and the profile of a new media consumer: autonomous, collaborative, and quick in terms of consuming and producing messages. Further, he argues that this is not a mere assumption; it is a fact that can be verified, just as one can verify that the "replacement of rural TV viewers with urban ones transformed TV content in the 1960s". (JERKINS, 2008, p. 95)

Thus, a challenge has been posed to generalizing media such as network TV, forced to develop generalizing shows, whilst facing pressure to design content to allow audiences to immerse themselves in digital technologies equipped with mobile and participatory devices, with high definition images, running a business model based around advertising and its relation with audience numbers. In countries like the US, for example, where the business model for TV broadcasting is very similar to the Brazilian one, this framework has already been influenced by the strategic attitude of TV networks.

\section{The industry adopts a stance, at least in the USA}

American network TV stations, considered the largest in the world, has seen its audience levels threatened by wireless technologies, on top of the long-standing competition with cable TV and the Internet. Data from 2011 pint out that only 10\% of Americans watch conventional $T^{7}{ }^{7}$. Those viewers are the ones who do not have enough money to pay for packages either on the Internet or cable TV. Consequently, traditional broadcasters do not appeal to great announcers/sponsors. To make 
matters worse, news in the press has revealed that telecommunication companies have been pressing the American government to force certain TV broadcasters to give back their broadcasting frequency in order for those companies to use it for mobile internet services, putting an end to the age of American TV broadcast.

From the end of the 1970s and the beginning of the 1980s onwards, TV broadcasting has seen a gradual decrease in audience due to the rise of private broadcasters (DIZARD, 2000). Financial developments such as manufactured products and those relating to the Wall Street stock market, beginning in the 1980s, have meant that thousands of Americans and immigrants have been losing their jobs and purchasing power. The value of a merchandizing ad has fallen along with investments in broadcasters (JAFE, 2005). In addition, groundbreaking technologies, which allow users to access contents more easily and quickly from almost anywhere, that were used almost exclusively by TV and radio networks, have also become more accessible to ordinary citizens. The solution found by the broadcasters was a series of merging and acquisitions since the 1990s, mainly with major cinema studios (DIZARD, 2000, p. 133).

Nowadays, in order to challenge competitors who own licenses for online broadcasting devices and to enforce telecommunication enterprises, the American television industry has been investing in the viewers' experience with the medium, mainly due to the high image quality. Ben Keen, CEO of Screen Digest, stated at the annual NAB (National Association of Broadcasters) meeting in 2012, that in order to obtain any relevance in such a dynamic, mutating market as has recently been shown, a television broadcast must be ahead of technological migration, and that the key to this process is to broaden the audience's experience with the set through images of higher and higher quality definition, further delivering this content via mobile devices which can be used wherever the consumer desires (KEEN, 2012).

The message from broadcasters, at least in the US, seems to be: produce content that we distribute, but produce with quality and at low cost. In a sector that has been losing advertising investments to other media, producing at low cost is a question of survival (FILHO, 2012). While in Brazil, solutions are still being sought for problems with HD $T V$, equipment suppliers for content production offer innovations such as $4 \mathrm{~K}$ technology, which is not only a new format, but also a system of production that will impact the entire audiovisual sector, mainly in Brazil, where TV broadcasters produce almost all their content, because this is exactly the point where the Brazilian model of television encounters the 
path paved by international broadcasters.

In the US, TV broadcasters produce only journalistic content, while entertainment content is produced either by independent makers or producers linked to the movie industry. With the new $4 \mathrm{~K}$ technology, production have surely dwindled because the new cameras make it possible to capture high quality image scenes using just natural light, further lowering costs in the post-production process. On the other hand, journalistic content has also had his producing budget cut down. It is no coincidence that large stands at the 2012 NAB show ${ }^{8}$ presented equipment which allows virtual set creation and external image caption through compact cameras. Lower costs in production infrastructure mean savings in lighting equipment and electricity expenses, as well as carpentry, props and finally, in the number of employees. Ultimately, companies specializing in signal distribution presented converters that can radiate signals to TVS and mobile devices, and also broadband TV systems.

However, this strategic positioning of American industry may not be adequate for Brazil. There is no interactivity, Brazilian stations produce both entertainment and journalistic content, and there is little regional programming and independent production is still incipient.

Thus, a strategic decision should be taken: invest in new equipment, which would be as costly as the investments made in migrating to the HD system; or open the doors to independent production? The network structure and generation plants that have been the pillars of Brazilian TV's success for over 60 years might become obsolete or too large and expensive to maintain satisfactorily the quality of the programming, in spite of the high revenue from advertising.

\section{Audiovisual journalism on other screens}

Another point that must be taken into consideration is the popularization of the so-called second screen. Brazilian broadcasters have pointed out that the interactivity promised by digital TV will be on those devices (smartphones and tablets) but not really on the TV screen. At the Brazilian TV Engineering Society Congress - BSEC - in 2012, it was clear from the number of sessions dedicated to the theme, that the consumption of video via the Internet and connected TVs will soon impact the Brazilian audiovisual market. Some may consider that this context is very distant from Brazilian reality, but the demand for video content has been growing all over the world, especially in Brazil, as demonstrated in 
the figures presented by invited speakers.

Breno Fleury, a Sisco company representative, responsible for developing business video for Latin America, presented important data illustrating this new reality and shattering some myths regarding the issue. The research points out that in 2016, the number of internet users in Brazil will increase from the current 61 million (first half of 2012) to 98 million users. He forecasts that the average speed of broadband connections will rise from the current $4.9 \mathrm{Mb}$ to $13.6 \mathrm{Mb}$ (FLEURY, 2012). It is a significant expectation to be achieved within just four years.

This new configuration of the broadband market will fulfill the desire to consume video via the internet. According to data presented by Fleury (2012), more than $50 \%$ of the worldwide traffic on the Internet is currently composed of videos and, unlike what was previously believed, it is not only adolescents who consume this kind of content. In Brazil, $92 \%$ of people aged 18 to 29 said they consumed online videos, while $82 \%$ of people aged 49 to 59 also stated they consumed online videos. Thus, regardless of age, people end up migrating or consuming with greater intensity online videos. As several companies demonstrated at the congress in 2012, the experience with interactive content for a second screen revolves primarily around games and sports broadcasts. However, the potential of this new modality of audiovisual consumption is adequate to fulfill the habit that has developed among viewers with internet access: the consumption of network television shows while surfing the Internet.

The so-called "digital generation" has had two major effects on the media market: the new informational structure, which is interconnected online in real time; and the user's new behavior regarding the consumption of media products due to having access to new content distribution devices, the so-called $Y$ generation. What could have been considered a disaster to the network TV business model some time ago has proven to be a new business opportunity for both managers and executives who can identify new opportunities, including for journalism, and who are flexible enough to abandon the old management model. It is increasingly apparent that the business model of network TV, based almost exclusively on advertising and the commercialization of interval ads in relation to viewer numbers, will not remain unfazed by the changes which have been imposed by the digital generation.

The other facet of this new generation involves the way in which content is distributed around the physical structure of computer networks. Transmission no longer occurs just by air; it has been migrating to the 
Internet at an unbelievable speed. The demand for video consumption on the internet has increased at an astonishing rate, even in Brazil, where $75 \%$ of the population has access only to the basic devices: TV sets with reception for open programs; and PCs connected to an internet system which runs data from $256 \mathrm{~Kb}$ to $2 \mathrm{Mb}$ (BITTENCOURT, 2012). The more affluent social classes either purchase devices that can be connected to the TV sets, such as DVD players, Blue-Ray readers, games and OTT services $^{9}$, or own smart TV sets with internet connections. In addition to those two configurations, there is the growing demand for mobility by forcing content producers to design multiplatform products, which currently is an expensive process and generally depends on Wi-Fi or mobile networks (BITTENCOURT, 2012).

In this context, Brazil is in a privileged position because it is the only country where commercial network TV has seen yearly increases billings from advertizing (MANZANO, 2012). It is due to factors linked to economic policies which have been adopted by the Brazilian government lately, to an increase in the Brazilian C class's purchasing power, and the relatively smaller access of citizens to broadband internet services, etc. Hence, there is sufficient time for radio broadcasters to analyze the changes and plan migration strategies for their contents to the worldwide web. It is a time-frame that other countries such as the US do not benefit from, due to their market characteristics. However, it is increasingly evident that the model needs to change. The context is digital but the management is still analogical, which could be problematic for those who do not migrate to an innovative form of management.

\section{Final Considerations}

The present conjecture has revealed that the migration of journalistic content to digital and mobile devices is not a mere technological procedure, nor will its adaptation take place with regard only to content construction. It would be short-sighted not to refer to McLuhan (1996) in this context, and his phrase which impacted the whole world of communication (the means is the message), or confirm that the migration of digital content must come from serious research that also examines the structure of the specific language of the new medium, while the previous model establishes itself more and more, as is the case with open TV broadcasters. In this framework, the research which is currently being developed through collaboration with UNESP TV draws attention to the issue that precedes content production. It does 
not mean the attempts developed for innumerous content designers, journalistic departments, graduating students and researchers are not valuable; quite the opposite. With the dynamics of migration occurring at a faster and faster pace, it is indispensable that studies and researchers also focus on content design, empirical knowledge construction and even on success-and-failure procedures. Thus, this study has completed its first stage in outlining the procedures which lie at the heart of digital migration and the productive procedures involved in developing informative audiovisual content for both digital and mobile devices. These procedures are decisive for achieving efficient communication and production vis-à-vis the audience.

Understanding the structure and architecture of information and the web, the procedures of information cognition and the relationship of the subjects with the new means, how this new design can survive through new business models and what are the new social demands for information, are what will allow content migration of journalistic content to happen on a solid foundation that can provide the experience with new genres and formats of shows, designed for new means and free of the previous means limitations. As McLuhan explains, "A new medium never adds itself to the old one, nor leaves the old one in peace. It never stops burdening the previous means until new configurations are found for it" (MCLUHAN, 1996, p. 199), meaning that when a medium is inserted in a society, the major changes happen on the previous means, forcing it to find new positions, functions and practices, to survive. It has been this way in painting, photography, cinema, radio, and now on television, mainly its journalistic dimension.

\section{NOTES}

1 In this study, Primus's (2007) use of the term interaction is adopted; hypertextual interaction as reactive interaction, since it flourishes from pre-shaped elements. Another form of interaction established by the author is mutual interaction, characterized by the possibility of collective construction and cooperation between writer and reader.

2 Nos parece que la palabra webperiodismo es la que mejor se adecua al periodismo hecho en y para Internet, más específicamente, en la parte de Internet denominada World Wide Web. Por lo tanto, lo que entendemos 
por webperiodismo es el periodismo que utiliza las herramientas de Internet para investigar y producir contenidos periodísticos difundidos por la Web, y que tiene un lenguaje proprio compuesto por textos, sonidos, imágenes y animaciones, conectados entre si a través de enlaces (CANAVILHAS, 2007, p. 6-7).

3 Tanto o rádio quanto a televisão eram gratuitos e pagos pela propaganda. Era o início do chamado modelo de mídia para o Grátis: um terceiro (o anunciante) subsidia o conteúdo, de modo que uma das partes (o ouvinte ou espectador) possa recebê-lo gratuitamente (ANDERSON, 2009, p. 139).

4 A narrativa dos telejornais é, portanto, estruturada e construída a partir dos blocos, separados por intervalos comerciais, responsáveis por quatro princípios de enunciação do discurso dos noticiários: "a relaxação, a fragmentação, a dramatização e a comercialização". A atenção conquistada pela escalada pode se diluir logo no primeiro intervalo. Por isso, no final dos blocos, há uma chamada, a passagem de bloco, para aguçar a curiosidade ou despertar o interesse do espectador sobre as notícias que serão transmitidas após o intervalo comercial. O jornal precisa seduzir e conquistar a audiência o tempo todo. (BECKER, 2005, p. 77-78)

5 "[...] com a Web, um meio em que a mídia não tem posição privilegiada, esse modelo já não sustenta mais nada" (ANDERSON, 2009, p. 139).

6 COPS is a FOX network TV show created in 1989 which is still broadcast by Langley Productions. The show format follows that of a documentary depicting policemen's routines on duty around several North-American cities. Released on <http://www.cops.com/>. Real World is a NorthAmerican MTV show produced by Mary-Ellis Bunim and Murray Jonathan. Its format is very similar to Big Brother's; young people are invited to live together in a house and have their actions observed constantly. The difference is that on each season, a new city is chosen foe the house. Released on <http://remotecontrol.mtv.com/category/shows/the_real_ world/>. Big Brother is perhaps the most popular type of reality show in Brazil nowadays. The Brazilian version of the show will have its $13^{\text {th }}$ season in 2013. Survivor is a competition reality show from the United Kingdom developed by Charlie Parson. Contestants are isolated in a wild and challenging environment where they must carry out several tasks to remain in the competition. In Brazil, Globo Network produced No Limite, a Brazilian version of Survivor. Released on <http://pt.wikipedia. org/wiki/Survivor>. American Idol is also a very popular reality show in Brazil, having different versions throughout TV stations. Talented youths perform a kind of audition in front of a panel with the aim of becoming 
pop stars.

7 Verbal information presented by Fernando Bittencourt at the Brazilian TV engineering society congress on August 21 st, 2012 in São Paulo.

8 The NAB show is the largest TV production and engineering fare in the world. It is part of the (NAB) Congress, an institution representing NorthAmerican radiobroadcasters. This fare takes place in Las Vegas yearly.

9 OTT (over-the-top) services are a range of products that can be delivered to the consumer without the provider having any control over content. The provider can be aware of IP-package contents, but they are neither responsible for it nor able to control viewing capabilities, copyright and redistribution of the content to the other users connected. The consumers can access OTT content through devices connected to the Internet, such as PCs, laptops, tablets, smartphones, set top boxes, smart TVs and Wii, PlayStation 3 and $\mathrm{Xbox} 360^{\circ}$ games consoles, as well as Blue-ray readers.

\section{REFERENCES}

AGNER, Luiz; MORAES, Anamaria. Diálogo Usuários-Organizações na World Wide Web: Avaliação Ergonômica de Interfaces HumanoComputador. In: MORAES, Anamaria (Org.). Design e Avaliação de Interface. Rio de Janeiro: IUSER, 2002.

ANDERSON, Chris. Free: grátis: o futuro dos preços. Tradução Cristina Yamagami. Rio de Janeiro: Elsevier, 2009.

BECKER, Beatriz. A linguagem do telejornal: um estudo da cobertura dos 500 anos do descobrimento do Brasil. $2^{\mathrm{a}}$ ed. Rio de Janeiro, E-papers Serviços Editoriais, 2005.

BITTENCOURT, Fernando. A geração Digital. Paulo: Congresso da Sociedade de Engenharia de Televisão/SET, 27, de agosto, 2012. Palestra ministrada aos congressistas

BRIGGS, Mark. Jornalismo 2.0: como sobreviver e prosperar - um guia de cultura digital na era da informação. Tradução de Carlos Castilho e Sonia Guimarães. Fundação Knight, 2007.

BUCCI, Eugênio. Ver TV de olhos fechados. TV Cultura. (1 DVD). DVD). O papel da mídia na sociedade digital. Cursos CPFL. ( 1 CANAVILHAS, João. Webnotícia: propuesta de modelo periodístico 
para la www. Portugal: Universidade da Beira Interior/Labcom, 2007.

Do jornalismo online ao webjornalismo: formação para a mudança. 2006. Available at: <www.bocc.ubi.pt>. Accessed on: 11 abr. 2008.

CASTELLS, Manuel. A sociedade em rede - A era da informação: economia, sociedade e cultura. Volume 1, 6. ed. São Paulo: Paz e Terra, 2002.

DIZARD, Wilson. A nova mídia. Tradução Antonio Queiroga e Edmond Jorge. Rio de Janeiro: Zahar, 2000.

JAFFE, Joseph. O declínio da mídia de massa: por que os comerciais de TV de trinta segundos estão com os dias contados. São Paulo: M.Books, 2005.

FIDALGO, Antonio. O jornalismo online segundo o modelo de Otto Groth. Available at: < http://www. www.bocc.ubi.pt> Accessed on: 23 jan. 2012.

FILIPÉRA. HyperEspaço 2.0 - o novo jornalismo, segundo

Carlos Cardoso. Available at: < http://www.nerdssomosnozes. com/2011/02/hyperespaco-20-o-novo-jornalismo.html>. Accessed on: 23 jan. 2012 .

FILHO, Francisco Machado. O problema é não é a audiência é o conteúdo. Produção Profissional, São Paulo, n. 125, p. 24, 2012.

FLEURY, Breno. Impacto das novas ofertas convergentes Broadcast/Broadband nas redes Telecom. São Paulo: Congresso da Sociedade de Engenharia de Televisão/SET, 26, de agosto, 2012. Palestra ministrada aos congressistas.

GIL, Antonio Carlos. Como elaborar projetos de pesquisa. São Paulo: Atlas, 1991.

JENKINS, Henry. Cultura da convergência. Tradução Susana Alexandria. São Paulo: Aleph, 2008.

KEEN, Bem. O futuro da TV. Las Vegas: Congresso da National Association of Broadcasters - NAB, 14, de abril, 2012. Palestra ministrada aos congressistas.

LÉVY, Pierre. O que é virtual? Tradução de Paulo Neves. São Paulo: Editora 34, 1996.

MANZANO. Rodrigo. Mercado cresce 8,5\% e TV tem share record. Available at: <http://www.meioemensagem.com.br/home/midia/ noticias/2012/03/05/Mercado-cresce-8-5--e-TV-tem-share-recorde. html> Accessed on: 04 de out. de 2012. 
MCLUHAN, Marshall. Os meios de comunicação como extensão do homem. São Paulo: Cultrix, 1996.

PALACIOS, Marcos. Ruptura, continuidade e potencialização no jornalismo on-line: o lugar da memória. In: MACHADO, Elias; PALACIOS, Marcos (Orgs.). Modelos de jornalismo digital. Salvador: Edições GJol/Calandra, 2003, p. 13-36.

SANTAELLA, Lucia. Navegar no ciberespaço: o perfil cognitivo do leitor imersivo. São Paulo: Paulus, 2004.

SOUZA, José Carlos Aronchi de. Gêneros e formatos na televisão brasileira. São Paulo: Summus Editorial, 2004. 
AUDIOVISUAL JOURNALISM:

BRAZILIAN JOURNALISM RESEARCH-Volume 8-number z- zOIz| 151 